\title{
KONTEKSTUALITAS AYAT-AYAT HUKUM WAKAF DI INDONESIA
}

\author{
Neneng Hasanah \\ Pascasarjana UIN Sunan Gunung Djati Bandung \\ Email : hasanahneneng515@gmail.com
}

\begin{abstract}
Waqf is a form of worship by separating some of our belongings to be used as common property, for the benefit of Muslims or people in general. In order to make waqf's benefits more applicable and accessible for all, the management must be maximally monitored. With innovative management and intensive supervision, waqf is expected to become productive and empower the mauquf 'alaih (waqf eligible receiver) and make them independent economically, health and education. With the library research method and content analysis on the interpretation of related al-Quran verses, none explicitly mentions the word waqf. But the Islamic scholars have agreed that infaq and shadaqah jariyah is the essence of waqf. Waqf are long-lasting infaq and shadaqah jariyah, as long as the asset is still used then the reward still flows to 'wakif even though he has passed away.
\end{abstract}

\section{Keywords:}

waqf, productive waqf, Indonesian Waqf Board

\begin{abstract}
Abstrak
Wakaf merupakan satu bentuk ibadah dengan cara memisahkan sebagian harta benda yang kita miliki untuk dijadikan harta milik umum, yang akan diambil manfaatnya bagi kepentingan umat islam atau manusia pada umumnya. Agar keberadaan wakaf dan hasilnya dapat dirasakan oleh semua lapisan masyarakat, maka pengelolaan dan pengawasannya harus diberdayakan dan diawasi secara maksimal. Dengan cara-cara pengelolaan yang bersifat inovatif dan pengawasan/ monitoring secara intensif yang kemudian wakaf tersebut menjadi produktif sehingga berdaya guna dan menjadikan para mauquf 'alaih menjadi mandiri secara ekonomi, kesehatan dan pendidikannya. Dengan metode library research dan content analysis terhadap penafsiran beberapa ayat Al-Quran yang terkait, tidak satupun secara eksplisit menyebutkan kata wakaf. Tetapi para ulama fiqih sudah sepakat bahwa infaq dan shadaqah jariyah yang dimaksud intinya adalah wakaf, karena wakaf adalah infaq dan shadaqah jariyah yang bertahan lama, selama harta tersebut masih digunakan maka pahalanya tetap mengalir kepada'si wakif sekalipun ia sudah meninggal dunia.
\end{abstract}

$$
\begin{gathered}
\text { Kata Kunci: } \\
\text { wakaf, wakaf produktif, Badan Wakaf Indonesia }
\end{gathered}
$$

\section{Pendahuluan}

Dalam ajaran Islam ada dua dimensi utama hubungan yang harus dipelihara, yaitu hubungan manusia dengan Tuhannya (hablun min-Allah) dan hubungan manusia dengan manusia lainnya (hablun min al-nas) dalam masyarakat serta benda yang ada di sekitarnya. Kedua hubungan tersebut harus senada dan seirama secara serentak, dan harus berjalan dengan baik dan sesuai dengan aturan yang berlaku dalam syari'at Islam. 
Dalam pelaksanaan kedua hubungan tersebut, Allah telah mengatur caranya, baik dalam bentuk ibadah khusus yang telah ditentukan caranya, waktu dan tempatnya, seperti shalat, puasa, dan haji, maupun dalam bentuk ibadah secara umum. Ibadah secara umum berupa pengabdian untuk kepentingan kemanusiaan, kemasyarakatan dan keagamaan. Hal ini dapat direalisasikan dengan pengorbanan berupa harta benda maupun ilmu pengetahuan yang kita miliki. Seperti zakat, infaq/shadaqah dan mengajar. Disamping ada juga secara bersama antara badan dan harta, seperti puasa dan haji. Satu bentuk ibadah melalui pengorbanan baik dengan harta maupun ilmu pengetahuan yang kita miliki untuk kepentingan masyarakat, kemanusiaan dan keagamaan, maka hal ini dalam ajaran Islam disebut dengan waqaf/shadaqah jariyah.

Wakaf merupakan satu bentuk ibadah dengan cara memisahkan sebagian harta benda yang kita miliki untuk dijadikan harta milik umum, yang akan diambil manfaatnya bagi kepentingan umat islam atau manusia pada umumnya. Amalan wakaf amat besar artinya bagi kehidupan sosial ekonomi, kebudayaan dan keagamaan. Oleh karenanya Islam meletakkan amalan wakaf sebagai satu macam ibadah yang amat digembirakan. ${ }^{1}$

Oleh karenanya, agar keberadaan wakaf dan hasilnya dapat dirasakan oleh semua lapisan masyarakat, maka pengelolaan dan pengawasannya harus diberdayakan dan diawasi secara maksimal. Dengan cara-cara yang sesuai dengan aturan Islam dan aturan pemerintah yang sudah di undang-undangkan, dengan kata lain ada pengelolaan yang bersifat inovatif dan pengawasan/ monitoring secara intensif yang kemudian wakaf tersebut menjadi produktif sehingga berdaya guna dan menjadikan para mauquf 'alaih menjadi mandiri secara ekonomi, kesehatan dan pendidikannya.

Dalam tulisan ini, penulis akan menggunakan metode library reasech sebagai bahan rujukan dan pedoman penulisan dengan mengungkap beberapa ayat hukum dan penafsiran para ulama tentang wakaf juga menggunakan metode field reasech sebagai bahan untuk menggali dan mengetahui implementasinya dalam kehidupan nyata juga sikap umat Islam di Indonesia dalam mengimplementasikan ayat-ayat wakaf. Sebagaimana diketahui bahwa beberapa ayat al-Qur'an yang akan diungkap, tidak satupun secara eksplisit menyebutkan kata wakaf. Tetapi para ulama fiqih sudah sepakat bahwa infaq dan shadaqah jariyah yang dimaksud intinya adalah wakaf, karena wakaf adalah infaq dan shadaqah jariyah yang bertahan lama, selama harta tersebut masih digunakan maka pahalanya tetap mengalir kepada'si wakif sekalipun ia sudah meninggal dunia.

\section{Terminologi Wakaf}

Wakaf adalah kata yang berasal dari bahasa Arab, bentuk asalnya adalah waqafa -yaqifu-waqfan, berarti secara bahasa adalah berdiri, abadi, berhenti dan menahan. Sedangkan secara isitilah adalah memberikan harta kekayaan dengan suka rela, atau suatu pemberian yang berlaku abadi, untuk kepentingan keagamaan atau untuk

\footnotetext{
${ }^{1}$. M. Daud Ali, Sistem Ekonomi Islam, Zakat dan Wakaf , (Jakarta:UI-Press, T.t.), hlm. 79.
} 
kepentingan umum. ${ }^{2}$ Kata lain yang memiliki arti sama dengan wakaf yaitu al-habs/altahbis dan al-tasbil yang berarti menahan atau menghentikan.

Wakaf menurut Jumhur Ulama (dua shahabat dari pengikut Imam Hanafi, Imam Syafi'i dan Imam Ahmad bin Hambal) adalah menahan harta benda yang mungkin dapat digunakan dijalan yang baik dan benar dalam rangka mendekatkan diri kepada Allah dan mencari ridha-Nya. Maka dari definisi ini, keluarlah harta tersebut dari milik si wakif dan menjadi milik Allah SWT., si wakif tidak memiliki kewenangan lagi dan ia wajib menyedekahkannya sesuai dengan tujuan wakaf. ${ }^{3}$

Sedangkan wakaf menurut KHI (Kompilasi Hukum Islam) adalah perbuatan hukum seseorang atau kelompok orang atau badan hukum yang memisahkan sebagian dari benda miliknya dan melembagakannya untuk selama-lamanya guna kepentingan ibadah atau keperluan umum lainnya sesuai dengan ajaran Islam. ${ }^{4}$

Wakaf menurut para mufassirin, mereka memaknainya dengan kata infak, shadaqah dan pengorbanan dijalan Allah atau melakukan kebaikan dalam rangka mendekatkan diri kepada Allah SWT. ${ }^{5}$

Dari beberapa definisi di atas, dapat disimpulkan bahwa wakaf dalam syari'at Islam jika dilihat dari perbuatan orang yang mewakafkan adalah suatu perbuatan hukum dari seseorang yang dengan sengaja memisahkan dan mengeluarkan harta dari milik pribadi, untuk diambil manfaatnya dengan tujuan kebaikan dalam rangka mendekatkan diri (taqarrub) kepada Allah SWT untuk mencapai keridhaan-Nya.

Oleh karenanya motivasi kaum muslimin untuk mewakafkan harta secara umum didorong oleh keinginan melakukan amal shaleh (shadaqah jariyah) dan didasari dengan beberapa ayat al-qur'an dan hadits Nabi SAW, maka dalam konteks shadaqah jariyah inilah kaum muslimin termotivasi untuk melakukan wakaf, karena amalan wakaf termasuk amalan yang amat besar pahalanya menurut ajaran Islam. Sehingga diharapkan selama harta wakaf tersebut masih dapat dimanfaatkan oleh kaum muslimin, maka pahalanya akan terus mengalir kepada yang memberikan wakaf walaupun yang bersangkutan telah meninggal dunia.

\section{Landasan Hukum Wakaf}

Walaupun kata wakaf secara harfiyah tidak terdapat di dalam al-Qur'an, tetapi para ulama fiqih dan mufassir sepakat bahwa kata infaq dan amal shalih yang ada dalam ayat-ayat yang akan dibahas adalah merupakan wakaf yang amalannya sudah terukur

\footnotetext{
${ }^{2}$ Cyril Glasse, Ensiklopedi Islam, (Jakarta: PT. Raja Grafindo Persada, 1999), hlm. 432

${ }^{3}$ Wahbah Al-Zuhaily, Al-Figh Al-Islamy wa Adillatuhu, (Beirut: Daar al-Fikr), jilid VIII, hlm. 153 .

${ }^{4}$ Abdurrahman, Kompilasi Hukum Islam di Indonesia, (Jakarta: Akademika Pressindo, 1992), cet. Ke-3 hlm. 165 .

${ }^{5}$ M. Ali Al-Shabuni, Shafwah Al-Tafasir, (Beirut: Dar al-Qalam, t.th.), juz I, hlm. 218., lihat pula dalam Al-Qurtubi, al-Jami'Li ahkami al-Qur'an, (Beirut: Daar Ihya al-Turats-al-Araby, t.th.) Juz. 3 hlm.132-133.
} 
dan jelas tujuan dan manfaatnya. Penulis akan menyajikan landasan hukum wakaf dari beberapa ayat dalam al-Quran dan hadits Nabi SAW sebagai pendukungnya, antara lain:

1. Dalam al-Qur'an Surat Ali Imran: 92,

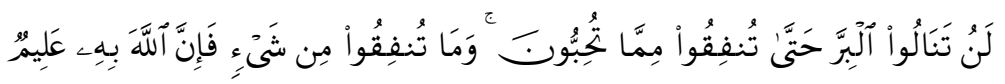

Kamu sekali-kali tidak sampai pada kebajikan (yang sempurna), sebelum kamu menafkahkan (menshadaqahkan) harta yang kamu cintai. Dan apa saja yang kamu nafkahkan, maka sesungguhnya Allah Maha Mengetahuinya.

Dalam kitab Mukhtas\{ar Tafsir Ibnu Katsir, Imam Ahmad dari Anas bin Malik, ia berkata: "Bahwasanya Abu T\{alhah adalah seorang kaya raya, memiliki salah satu kebun yang sangat ia cintai yaitu Bairuha', kebun tersebut menghadap ke Masjid Madinah, Rasulullah SAW selalu masuk ke dalam kebun tersebut dan meminum airnya yang sangat jernih". Anas berkata: "Manakala turun ayat ini (ayat di atas), Abu T\{alhah berkata: "Ya Rasulallah, sesungguhnya diantara hartaku yang sangat aku cintai adalah kebun Bairuha', aku menshadaqahkannya /mewaqafkannya untuk Allah SWT dan aku berharap akan kebaikan yang tersimpan di sisi Allah SWT, dan aku serahkan kepadamu ya Rasulallah sesuai ketentuan Allah, kemudian Nabi SAW bersabda: "Bakh, bakh, (bagus-bagus) alangkah mulia jiwanya, ${ }^{6}$ itulah harta yang mendatangkan keuntungan besar, itulah harta yang mendatangkan keuntungan besar, dan aku telah mendengar darimu, dan menurutku agar harta tersebut diberikan (dis\{adaqahkan) kepada kerabatmu." akan aku laksanakan ya Rasulallah. Kemudian Abu T\{alhah membagikannya kepada kerabatnya dan anak pamannya. (HR. Imam Bukhari dan Muslim) ${ }^{7}$.

Menurut hemat penulis, hadits ini adalah sebagai bayan (penjelasan) dari ayat di atas tentang adanya wakaf/shadaqah jariyah dengan menggunakan kata تُنِفُقواً yang kemudian dalam kitab al-Fiqh al-Islamy wa Adillatuhu karya Wahbah al-Zuhaily, menyatakan bahwa ada ulama yang membagi wakaf dari sisi mauquf 'alaih (peruntukkannya) kepada wakaf khairy dan wakaf ahli/dhurri (keluarga) ${ }^{8}$, dan untuk wakaf ahli/dhurri yang dalam konteks kekinian tidak diatur dalam undang-undang perwakafan, berbeda dengan bentuk wakaf khairy. Adapun wakaf khairi adalah wakaf yang yang diperuntukkan bagi kepentingan umum, jadi hasil dari pengelolaan wakaf dibagikan kepada orang yang membutuhkan bantuan sesuai dengan tujuan wakif (pemberi wakaf). Sedangkan wakaf dhurri adalah wakaf yang diperuntukkan bagi keluarga atau kerabat dekatnya, wakaf

\footnotetext{
${ }^{6}$ Ahmad Warson Munawwir, Al-Munawwir, (Yogyakarta:Pustaka Progressif, 1997), cet. Ke 14, hlm.
} 61.

\footnotetext{
${ }^{7}$ Muhammad Ali al-Sabuni, Mukhtashar Tafsir Ibnu Katsir, (Beirut:Daar al-Fikr, t.th), Jilid. 2, hlm. 299.

${ }^{8}$ Wahbah al-Zuahily, Al-Figh Al-Islamy wa Adillatuhu (Beirut: Daar-al-fikr, t.th), hlm. 159.
} 
semacam ini tidak di atur dan di undang-undangkan di Negara Indonesia karena sifatnya hanya sementara (muaqqat).

2. Dalam al-Qur'an Surat al-Hajj: 77,

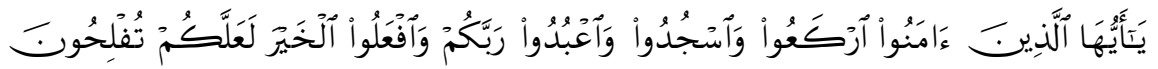

Wahai orang-orang yang beriman, rukuk dan sujudlah kamu dan sembahlah Tuhanmu, serta berbuatlah kebaikan supaya kamu mendapatkan kemenangan.

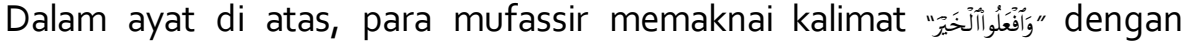
melakukan semua aktifitas yang baik dalam rangka mendekatkan diri (taqarrub) kepada Allah SWT. ${ }^{9}$ tidak ada satu orang pun yang tidak sepakat jika wakaf adalah perbuatan yang baik dan terpuji, melakukannya dalam rangka taqarrub kepada Allah SWT, mendatangkan banyak manfaat bagi umat utama lagi jika dikelola dengan baik, benar profesional dan sesuai dengan aturan yang berlaku di negara ini.

\section{Dalam al-Qur'an Surat an-Nahl: 97,}

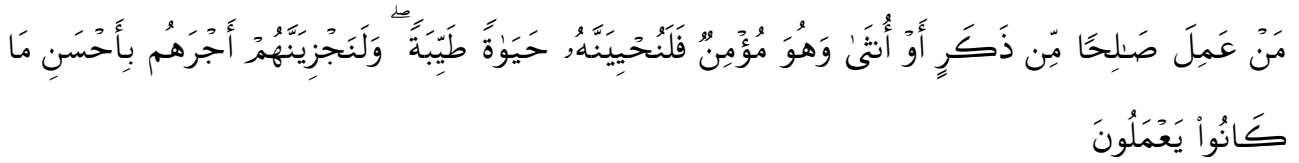

Barang siapa yang berbuat kebajikan, laki-laki atau perempuan dan ia beriman, niscaya akan Kami beri kehidupan yang baik dan akan Kami balas dengan pahala yang lebih baik dari apa yang mereka perbuat.

Dalam ayat di atas ditemukan pula kalimat "مَنَ عَمِلصَنِحًَا yang maknanya bahwa siapa saja melakukan beberapa kebajikan, apakah dia seorang laki-laki atau seorang perempuan, dengan syarat ketika melakukan kebajikan-kebajikan itu dalam bingkai iman kepada Allah, maka pasti akan Allah berikan pahala yang baik di dunianya dengan memiliki ciri-ciri sebagai berikut: (1). Orang tersebut memiliki sifat qana'ah dalam menjalani kehidupannya, (2). Selalu berusaha memperoleh dan memiliki rizqi yang halal, dan (3). Selalu berusaha untuk mendapatkan keridhan Allah SWT. dalam semua aktifitas yang dijalaninya. Adapun pahala akhiratnya adalah kelak akan dibalas dengan balasan yang lebih baik dari apa yang dia lakukan di dunia, yaitu berupa surga Allah SWT. ${ }^{10}$

Bila diperhatikan ayat-ayat di atas tidak ada kata-kata wakaf yang disebutkan secara eksplisit, melainkan yang ada adalah kata infaq/shadaqah. Tapi bukan berarti itu adalah salah ayat/dalil, justru itulah ayat yang dijadikan rujukan dan pegangan oleh para ulama sebagai dalil wakaf sebagaimana dijelaskan oleh hadits Rasulullah SAW. Untuk lebih jelasnya penulis akan memberi skema perbedaan antara wakaf dan shadaqah.

\footnotetext{
${ }^{9}$ Al-Sabuni, Safwahal-Tafasir, hlm. 300.

${ }^{10}$ Al-Sabuni, Safwah al-Tafasir, hlm. 142. lihat pula dalam Al-Qurtuby, Al-Jami' Li ahkami al-Qur'an, juz $10 \mathrm{hlm}$. 173.
} 
Tabel 1

Perbedaan Wakaf dan Shadaqah

\begin{tabular}{|l|l|l|l|}
\hline No & \multicolumn{1}{|c|}{ Hal } & \multicolumn{1}{c|}{ Wakaf } & \multicolumn{1}{c|}{ Shadaqah } \\
\hline 1. & Tujuan & $\begin{array}{l}\text { Kebaikan umum dan } \\
\text { khusus, kaya dan miskin }\end{array}$ & $\begin{array}{l}\text { Kebaikan umum dan } \\
\text { khusus, kaya dan miskin }\end{array}$ \\
\hline 2. & $\begin{array}{l}\text { Keluarnya harta dari } \\
\text { wewenang pemiliknya }\end{array}$ & Keluar & Keluar \\
\hline 3. & $\begin{array}{l}\text { Pemilik bisa mengambil } \\
\text { manfaatnya }\end{array}$ & Bisa & Bisa \\
\hline 4. & Jenis harta & $\begin{array}{l}\text { Benda tetap, benda } \\
\text { bergerak dan manfaat }\end{array}$ & $\begin{array}{l}\text { Benda tetap, benda } \\
\text { bergerak dan manfaat }\end{array}$ \\
\hline $5 \cdot$ & Model pemberian & Terus berlanjut & Sekali saja \\
\hline 6. & Keutuhan barangnya & $\begin{array}{l}\text { Tetap, apabila } \\
\text { dipertahankan }\end{array}$ & $\begin{array}{l}\text { Tetap apabila } \\
\text { dipertahankan }\end{array}$ \\
\hline
\end{tabular}

Dari penjelasan di atas diketahui bahwa shadaqah dan wakaf mempunyai satu tujuan yang sama, yaitu untuk tujuan kebaikan, baik umum (khairi) maupun khusus (dhurri)/keluarga, kaya maupun miskin atau orang lain, tergantung pada kebutuhan mereka. ${ }^{11}$

Selain ayat-ayat di atas, ada pula beberapa hadits yang masyhur sebagai landasan untuk menunaikan wakaf, antara lain adalah :

1. Hadits dari Abu Hurairah ra., Rasulullah SAW bersabda: "Jika seorang Bani Adam meninggal dunia, maka terputuslah amalnya, kecuali tiga perkara: shadaqah jariyah, ilmu yang bermanfaat, dan anak yang shalih yang mendoakannya." (HR. Muslim).

Para ulama menafsirkan kata shadaqah jariyah dalam hadits tersebut adalah dengan wakaf, sejalan dengan penafsiran ulama dalam hadits tersebut al-Qurtubi dalam Kitab tafsirnya al-Jami' Li ahkam al-Qur'an, mengungkap bahwa ayat 92 surat Ali Imran tentang infaq juga bermakna s\{adaqah jariyah atau amalan-amalan lain yang menjadikan taat, tunduk dan patuh kepada Allah SWT. ${ }^{12}$ Dalam hadits dan ayat alQur'an yang sudah ditafsirkan oleh para ulama di atas, penulis menyimpulkan bahwa inti dari infak/shadaqah jariyah yang sangat relefan adalah wakaf, karena wakaf merupakan refleksi ketundukan kepada Allah melalui ibadah maliyah/harta sebagai jalan mendekatkan diri kepada Allah SWT.

2. Hadits Nabi dari Utsman bin 'Affan ra. Bahwasanya sesampainya Rasulullah SAW ke Madinah, beliau tidak menemukan air yang jernih kecuali sumur raumah, maka beliau bersabda: "Barang siapa yang membeli sumur raumah, kemudian memasukkan timbanya dengan timba umat Islam, maka akan dibalas dengan kebaikan yang lebih

${ }^{11}$ Mundzir Qahaf, Manajemen Wakaf Produktif, Penj. Muhyddin Mas Rida (Jakarta: Khalifa, 2007), hlm. 106-107.

${ }^{12}$ Al-Qurtuby, Al-Jami' Li ahkami al-Qur'an, (t.t. : t. pn. t.th), jilid 3. hlm. 132-133. 
baik dari sumur Raumah di surga. Kemudian aku membelinya dengan uangku sendiri "(HR. Nasa'i, dan Tirmidzi, hadits hasan). Hadits tersebut menjelaskan bahwa Utsman bin Affan membeli sumur tersebut yang terletak di Madinah, kemudian beliau mewakafkannya untuk kepentingan umum dan beliau sendiri menggunakannya untuk kepentingan sehari-hari. ${ }^{13}$

3. Dalam hadits Rasulullah SAW tentang wakaf yang dilakukan oleh sahabat Umar bin Khattab ra.

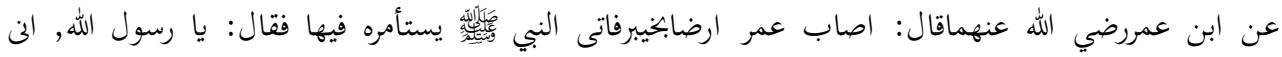

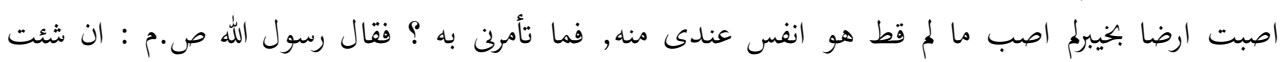

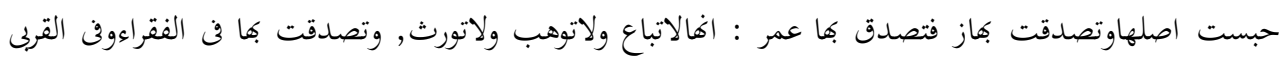

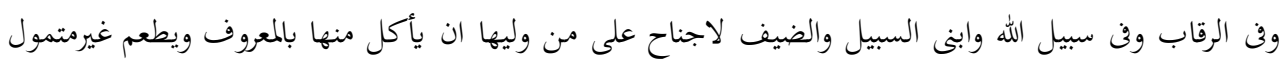

$$
\begin{aligned}
& \text { (رو البخارى) }
\end{aligned}
$$

Dari Ibnu Umar ra bahwasanya umar bin Khattab mendapat bagian sebidang kebun di khaibar, lalu ia datang kepada Nabi saw untuk meminta nasihat tentang harta itu, ia berkata "Ya Rasulallah, sesungguhnya aku telah mendapat sebidang kebun di Khaibar yang aku belum pernah memperoleh tanah seperti itu, apakah nasihat engkau kepadaku tentang tanah itu? Rasulullah menjawab "Jika engkau mau, wakafkanlah tanah itu dan bersedekahlah dengan hasilnya "Berkata Ibnu Umar : "Maka Umar mewakafkan harta itu dengan arti bahwa tanah itu tidak boleh dual, dihibahkan dan diwariskan. la menyedekahkan hasil harta itu kepada orang fakir, kepada kerabat, untuk memerdekakan budak, orang yang terlantar dan tamu. Tidak ada dosa bagi orang yang mengurusnya (nadzir) memakan sebahagian harta itu secara patut atau memberi makan asal tidak bermaksud mencari kekayaan. (Muttafaq Alaihi). ${ }^{14}$ Dan dalam hadits Amar bin Dinar, dia berkata mengenai sedekahnya Umar itu sebagai berikut "tidak berdosa seorang pengurus untuk makan dan memberikan makan kepada kawan (keluarganya), asalkan tidak sampai dikuasai pokoknya. Dia juga mengatakan: "Dan Ibnu Umar adalah seorang yang mengurusi sedekah Umar tersebut, dan diapun memberikan hadiah kepada orang-orang dari penduduk Makkah dan dia sendiri yang datang kepada mereka. (H.R. Bukhari). ${ }^{15}$

\section{Sekilas tentang Implementasi dan Problematika Wakaf di Indonesia}

Wakaf adalah lembaga Islam kedua tertua di Indonesia setelah perkawinan, sejak zaman awal telah dikenal wakaf masjid, mushalla dan wakaf tanah pemakaman di berbagai wilayah di Indonesia. Selanjutnya muncul tanah wakaf untuk pesantren, madrasah dan tanah wakaf untuk pertanian yang digunakan hasilnya untuk membiayai pendidikan Islam dan wakaf yang lainnya.

\footnotetext{
${ }^{13}$ Muhammad bin Ali al-Syaukani, Nail al-Autar, (Beirut: Daar al-Kitab al-'Araby. t.th). hlm. 1095.

${ }^{14}$ Imam Abu Husain Muslim bin Hajjaj al-Qusyary "Shahih Muslim" (Mamalakah `Arab al-Su'udiyah. t.th. ), Juz III. HIm. 1255 .

${ }_{15}$ Muhammad bin Isma'il al-Bukhary. Al-Bukhary (Semarang: Maktabah Usaha Keluarga. t.th.) Juz 11 hal. 44. Lihat pula M. Al-Syaukany dalam Nailul Authar. T.t : t.pn. t.th.) hlm. 24.
} 
Masalah perwakafan di Indonesia telah ada sejak zaman penjajahan Belanda, wakaf sebagai lembaga keuangan Islam telah tersebar di berbagai persada Nusantara. ${ }^{16}$ Dengan berdirinya Peradilan Agama berdasarkan Staatsblad No. 152 pada tahun 1882, maka dalam praktek yang berlaku masalah wakaf menjadi salah satu wewenangnya disamping masalah lain yang menyangkut urusan yang berhubungan dengan agama Islam.

Di zaman kemerdekaan, masalah wakaf semakin mendapat perhatian yang lebih dari pemerintah, melalui Departemen Agama RI. Seperti adanya Intruksi Bersama Menteri Agama dan Menteri Dalam Negeri No. 1 Tahun 1978 tentang pelaksanaan PP. No. 28 Tentang Perwakafan Tanah Milik Tahun 1977. Kemudian Intruksi Menteri Agama No. 15 Tahun 1989 tentang PAIW dan Sertifikat Tanah Wakaf. Keputusan Dirjen Bimas Islam dan Urusan Haji No. 15 Tahun 1990 tentang penyempurnaan formulir dan pedoman pelaksanaan peraturan-peraturan tentang perwakafan Tanah MILIK. Surat edaran Dirjen Bimas Islam dan Urusan Haji No. D 11/5/HK/007/901/1989tentang Petunjuk Perubahan Status/Tukar Menukar Tanah Wakaf. ${ }^{17}$ Dan banyak lagi aturan lain tentang wakaf yang menjadi payung hukum keberadaanya.

Keberadaan wakaf yang sudah mendapatkan legitimasi hukum di Indonesia ini menjadi semakin banyak secara kwantitatif. Dari wakaf tanah milik pribadi saja telah banyak menolong kebutuhan umat Islam terutama dalam bidang sosial ekonomi dan keagamaan. Kebanyakan tanah wakaf diperuntukkan bagi pembangunan masjid, mushalla, perkuburan, madrasah dll. Sehingga dengan wakaf tersebut umat Islam tertanggulangi kebutuhannya terhadap hal-hal tersebut.

Selanjutnya perkembangan zaman yang semakin modern, maka wakaf di Indonesia belakangan ini pun menjadi perbincangan yang cukup menarik. Berawal dari krisis moneter tahun 1997 dan berkembangnya isyu-isyu ekonomi Syariah saat itu, bangsa Indonesia mulai menyadari akan pentingnya mengembangkan lembaga sosial keagamaan, seperti zakat dan wakaf. Pada tahun 1999, terbit Undang-undang pengelolaan zakat dan disempurnakan pada tahun 2011. Kemudian pada tahun 2004 terbit Undang-undang no. 41 tentang wakaf, serta pada tahun 2006 terbit Peraturan Pemerintah tentang Pelaksanaan Undang-undang Wakaf.

Lahirnya peraturan perundang-undangan wakaf tersebut dibangun atas semangat mulia, yaitu untuk membantu program pemerintah dalam meningkatkan kesejahteraan masyarakat. Sebelum regulasi dilaksanakan, paradigma pengelolaan zakat dan wakaf lebih pada pelaksanaan doktrin ibadah mahdhah semata. Namun, setelah regulasi peraturan perundang-undangan wakaf dilaksanakan, semangatnya dibangun untuk memberdayakan dan mengembangkan lembaga sosial keagamaan untuk meningkatkan kesejahteraan ekonomi umat.

\footnotetext{
${ }^{16}$ Rifyal Ka'bah. Wakaf Dalam Persepektif Hukum Nasional. (t.pn. Ultimatum. 2003), hlm. 23.

${ }^{17}$ Ka'bah. Wakaf Dalam Persepektif, hlm. 25
} 
Perkembangan tersebut menjadi momentum penting bagi umat Islam Indonesia, bahwa lembaga sosial keagamaan, khususnya wakaf yang memiliki tradisi kuat dalam Islam, perlu terus dikembangkan. Sebagaimana diketahui dari beberapa literatur Islam, bahwa wakaf merupakan soko guru perekonomian dalam sejarah peradaban Islam masa lalu, seperti yang disebutkan dari hadits dan tafsir di atas pada masa Rasulullah SAW dan diimplementasikan oleh para sahabat Rasul SAW. yang kemudian diikuti oleh umat Islam seluruh dunia termasuk Indonesia.

Berdasarkan pengalaman sejarah tersebut, masyarakat Indonesia melalui ormasormas Islam yang memiliki akses sangat luas terhadap pembinaan umatnya, telah mengambil perannya secara nyata. Ada beberapa catatan yang penulis ambil dari artikel jurnal al-Awqaf bahwa ormas Islam Nahdhatul Ulama (NU), aset-aset wakafnya lebih banyak berupa pemabngunan pesantren, masjid, dan lahan-lahan pertanian. Sementara di lingkungan Muhammadiyah telah dikelola dan dikembangkan secara lebih produktif melalui peran dan kontribusi lembaga amal usaha dalam bidang pendidikan, kesehatan, termasuk pemberdayaan ekonomi umat. ${ }^{18}$

Oleh karena itu, para pihak yang terus mengoptimalkan potensi dan peran wakaf yang ada untuk kepentingan umat ini perlu mendapat apresiasi dari semua kalangan. Melalui Direktorat Pemberdayaan Wakaf, Kementerian Agama, terus menggalakan "Gerakan Pemberdayaan Wakaf Produktif." Tujuan dari program ini adalah tumbuh kembangnya semangat para Nadhir dalam memberdayakan dan mengembangkan wakaf sehingga memiliki manfaat sebesar-besarnya untuk membangun peradaban Islam dan bangsa Indonesia.

\section{Problematika Perwakafan di Indonesia}

Problematika adalah sebuah keniscayaan dalam hidup ini, tidak terkecuali dalam masalah perwakafan di Indonesia, sebuah Negara yang memiliki wilayah yang sangat luas, penduduk muslim terbesar di dunia pasti kendala dan problem tersebut akan selalu mengitarinya. Sebelum adanya PP. NO. 28 tahun 1977 masalah yang dihadapi bangsa ini adalah sulitnya sertifikasi tanah wakaf, bangunan-bangunan, rumah-rumah ibadah dan lainnya, sulit dideteksi karena tidak ada bukti / akte wakaf dan lainnya, sehingga tidaklah mustahil jika harta wakaf yang sudah diikrarkan diambil kembali oleh keturunan atau keluarga wakif.

Kemudian usaha-usaha pemerintah melalui Kementerian Agama tentang adanya legitimasi badan wakaf yang akan menjadi payung hukum perwakafan di Indonesia, terus digulirkan. Seperti Undang-undang No. 41 Tahun 2004 tentang wakaf dan PP No. 42 Tahun 2006 tentang Pelaksanaan UU. No 41 Tahun 2004. Undang-undang dan Peraturan Pemerintah tersebut memberi amanah untuk segera dibentuk Badan Wakaf Nasional (BWI) yang bertugas untuk mengembangkan pengelolaan perwakafan di

\footnotetext{
${ }^{18}$ Sutami. Perkembangan Wakaf di Indonesia. (t.pn. Al-Awqaf. 2012), hlm. 15.
} 
Indonesia ke arah yang lebih profesional dan produktif sehingga wakaf benar-benar mampu memberi sumbangan pada perekonomian yang saat ini sangat memprihatin$\operatorname{kan}^{19}$

Adapun yang menjadi kendala atau problem perwakafan di Indonesia setelah terjawab dengan adanya payung hukum dan dibentuknya BWI, adalah berupa perwakafan yang ada di Indonesia ini hampir dapat dikatakan cenderung kepada konsumtif, jarang yang produktif. Kalaupun ada mungkin habis hanya untuk keperluan mauquf 'alaih (yang menerima dana wakaf) itu sendiri atau dengan kata lain sifatnya wakaf mubasyir (langsung) yang memiliki kekurangan yang harus diantisipasi oleh para nadhir dengan mencari dana dari sumber lain untuk biaya dan pemeliharaannya. Seperti wakaf tanah untuk pembangunan masjid, pesantren, dan madrasah.

Jika wakaf itu produktif (istitsmari) pun kalau pengelolaannya tidak benar (kurang inovatif) masih manual/tradisional atau belum maksimal pengelolaannya, maka hasilnya tidak dapat dirasakan oleh banyak orang dengan kata lain belum dapat memenuhi kebutuhan umat Islam dan pembangunan bangsa ini. Sedangkan yang diharapkan adalah wakaf yang pengelolaannya produktif, yang hasil produksi dari wakaf tersebut bukan hanya mencukupi diri mauquf 'alaih saja melainkan menjadi sumber dana untuk keperluan pembangunan umat.

Wakaf produktif adalah sebuah skema pengelolaan donasi wakaf dari umat, yaitu dengan memproduktifkan donasi tersebut, hingga mampu menghasilkan surplus yang berkelanjutan. Donasi wakaf dapat berupa benda bergerak, seperti uang dan logam mulia, maupun benda tidak bergerak, seperti tanah dan bangunan. Surplus wakaf produktif inilah yang menjadi sumber dana abadi bagi pembiayaan kebutuhan umat, seperti pembiayaan pendidikan dan pelayanan kesehatan yang berkualitas. ${ }^{20}$

Wakaf produktif yang dipelopori Badan Wakaf Indonesia adalah menciptakan aset wakaf yang benilai ekonomi, termasuk dicanangkannya Gerakan Nasional Wakaf Uang oleh Presiden Republik Indonesia pada tanggal 8 Januari 2010. Wakaf uang sebagai fungsi komoditi selain fungsi nilai tukar, standar nilai, alat saving adalah untuk dikembangkan dan hasilnya disalurkan untuk memenuhi peruntukannya.

Badan Wakaf Indonesia (BWI) yang sudah berusaha dengan segala kemampuannya untuk memaksimalkan keberadaan dan keberdayaan wakaf di Indonesia masih dirasa belum maksimal. Keberadaannya masih dalam tataran teori dan konseptual, sehingga sangat perlu pengimplementasian dari konsep yang ada dengan cara yang lebih efektif dan berkualitas. Semoga ke depan usaha yang sedang dirintis ini membuahkan hasil yang manis, wakaf yang ada di Indonesia ini mampu meminimalisir kemiskinan

19 Mustafa Edwin Nasution. Peran Badan Wakaf Indonesia (BWI) dalam Pengembangan Wakaf di Indonesia. (t.pn : Al-Awqaf. 2008), hlm. 1

20 http://www.kebunwakaf.com/site/tentang-wakaf/pengertian-wakaf-produktif lihat pula dalam Mundzir Qahaf, Manajemen Wakaf Produktif, (Jakarta: Khalifa. 2007), hlm.24-25. 
bahkan mengentaskan dan mengangkat derajat bangsa ini menuju bangsa yang mandiri tidak tergantung pada uluran tangan bangsa lain.

Sebagai solusi akhir, penulis menginginkan adanya sebuah kementerian wakaf di Indonesia yang mampu memberdayakan dan mengefektifkan pengelolaan harta wakaf yang sangat banyak di negara ini demi kepentingan umat dan perekonomiannya yang saat ini sangat memperihatinkan, sehingga problematika wakaf di negara ini akan terurai dan manfaatnya akan dirasakan oleh banyak kalangan. Karena kedudukan kementerian lebih luas dan aturan/kebijakannya dapat memaksakan masyarakat ketimbang kebijakan kelembagaan seperti BWI .

\section{Simpulan}

Sebagai akhir dari tulisan yang sangat sederhana dan sarat dengan kekurangan ini, penulis menyimpulkan bahwa sekalipun kata wakaf tidak diungkap secara eksplisit oleh al-Qur'an dan al-Hadits tetapi secara implisit dan maknawi tujuan dari ayat-ayat alQur'an dan al-Hadits yang penulis sebutkan merupakan gambaran perintah Allah dan Rasul-Nya untuk umat Islam agar melakukan sebuah amal shaleh yang berupa wakaf, karena wakaf itu berbeda dengan shadaqah yang lainnya, semisal infaq, hibah dan lainnya. Wakaf adalah sebuah shadaqah jariyah yang keberadaannya tahan lama, sangat membantu kebutuhan umat, baik dari sisi keagamaan, ekonomi bahkan kesehatan dan pendidikannya. Maka jika keberadaannya dikelola dengan produktif, akan memberikan manfaat yang lebih banyak bagi seluruh lapisan umat. la juga merupakan salah satu ibadah maliyat yang sangat dianjurkan Islam dan sudah dicontohkan oleh Rasulullah SAW, para sahabat dan salaf al-shhalih.

Dengan adanya Peraturan Pemerintah, undang-undang tentang perwakafan dan Badan Wakaf Indonesia yang menjadi payung hukum dan pengawas pelaksanaan pengelolaan harta wakaf, sangat diharapkan ke depan perwakafan di Indonesia akan menjadi lebih menggeliat dan bahkan mampu mengurangi kemiskinan yang melanda bangsa pada saat sekarang ini. Harapan harus selalu ada, yang diperintahkan Islam adalah usaha bukan hasil, hasil adalah hak prerogatif Allah Yang Maha Kuasa dan Maha Berkehendak. Dengan adanya usaha dari pihak umat Islam melalui pemerintah (kementerian agama), suatu saat keberadaan wakaf di Indonesia akan ada hasil yang maksimal seperti di negara-negara yang sudah menerapkan pengelolaan wakaf secara produktif seperti di Mesir, Bangladesh, Qatar dsb. Sebagai akhir dari tulisan ini, penulis berharap semoga rekan-rekan seperjuangan dapat kiranya memberi masukkan pada tulisan ini agar lebih baik dan dapat disempurnakan untuk menjadi bahan kajian dan referensi bacaan. Wallahu a'lamu bisshawabi 


\section{Daftar Pustaka}

Abdurrahman. 1992. Kompilasi Hukum Islam di Indonesia, Jakarta: Akademika Pressindo. cet. Ke-3

Al-Bukhary, Muhammad bin Isma'il. T.th. Al-Bukhary. Semarang: Maktabah Usaha Keluarga, Juz 11.

Ali Al-Shabuni, Muhammad, t.th. Shafwah Al-Tafasir. Beirut: Dar al-Qalam. juz I.

Ali al-Shabuni, Muhammad. Mukhtashar Tafsir Ibnu Katsir. Beirut: Daar al-Fikr, Jilid. 2.

Ali al-Syaukani, Muhammad. T.th. Nail al-Authar. Beirut: Daar al-Kitab al-'Araby.

Ali, M. Daud. 1988. Sistem Ekonomi Islam, Zakat dan Wakaf, Jakarta: UI Press

Al-Qurtubi, Abdullah Muhammad, t.th. Al-Jami'LiahkamiAl-Qur'an, Beirut: Daar Ihya alTurats-al-Araby) Juz. 3.

Al-Qurtubi. t.th. al-Jami'Liahkamial-Qur'an, (Beirut: Daar Ihya al-Turats-al-Araby).

Al-Shabuni, Muhammad. Ali. T.th. Shafwah al-Tafasir. Beirut: Dar al-Qalam.

Al-Zuahily, Wahbah. T.th. Al-Fiqh Al-Islamy wa Adillatuhu. Beirut: Daar-al-fikr.

Daud Ali, Muhammad. T.th. Zakat dan Wakaf. Jakarta: UI-Press

Edwin Nasution, Mushtafa. 2008. Peran Badan Wakaf Indonesia (BWI) dalam Pengembangan Wakaf di Indonesia. T.t. : Al-Awqaf, 1:01

Glasse, Cyril. 1999. Ensiklopedi Islam. Jakarta: PT. Raja Grafindo Persada

Muslim bin Hajajj, Abu Husain al-Qusyary. T.th. Shahih Muslim. T.t. : Mamlakah `Arab alSu'udiyah), Juz III.

Qahaf, Mundzir. 2007. Manajemen Wakaf Produktif, Penrj. Muhyiddin Mas Rida . Jakarta: Khalifa.

Rifyal, Ka'bah. 2003. Wakaf dalam Persepektif Hukum Nasional. T.t. : Ultimatum,1:4

Sutami. 2012. Perkembangan Wakaf di Indonesia. T.t. : al-Awqaf, 7:2

Warson Munawwir, Ahmad. 1997. Al-Munawwir. Yogyakarta: Pustaka Progressif. cet. ke 14.

http://www.kebunwakaf.com/site/tentang-wakaf/pengertian-wakaf-produktif 